\title{
Sentence Comprehension Ability and Working Memory Capacity as a Function of Syntactic Structure and Canonicity in 5- and 6-Year-Old Children
}

\author{
Shin-Young Kim, Jee Eun Sung, Dongsun Yim \\ Department of Communication Disorders, Ewha Womans University, Seoul, Korea
}

Correspondence: Jee Eun Sung, PhD Department of Communication Disorders, Ewha Womans University, 52 Ewhayeodae-gil, Seodamun-gu, Seoul 03760, Korea

Tel: $+82-2-3277-2208$

Fax: +82-2-3277-2122

E-mail: jeesung@ewha.ac.kr

Received: July 5, 2017

Revised: September 1, 2017

Accepted: September 25, 2017

This work was supported by the Ministry of Education of the Republic of Korea and the National Research Foundation of Korea (No. NRF-2017R1A2B4006604)

\begin{abstract}
Objectives: The purposes of this study were to investigate the effects of morphologic and syntactic cues on the sentence comprehension ability of preschool children, and to explore which working memory tasks significantly predict sentence comprehension ability. Methods: Eighteen preschool children (5- and 6-year-old) participated in this study. They performed a sentence comprehension task (SCT) along with five other working memory tasks. The SCT consisted of sentences with three different syntactic structures (active with 2-palce verbs, active with 3-place verbs, and passive) and two types of word order (canonical or non-canonical) which were manipulated within each syntactic structure. Statistical analysis was conducted using a two-way repeated ANOVA, an exploratory factor analysis, and a stepwise regression. Results: There was a significant main effect for sentence type, and the post-hoc comparison displayed lower accuracy in passive than active sentences. Canonicity effect was also significant, with better performance on canonical than non-canonical word order. The two-way interaction was significant as well, showing greater canonicity effects in active than passive sentences. Exploratory factor analysis revealed that working memory tasks could be classified into three different categories: verbal working memory tasks, matrix, and sentence repetition. The strongest predictor for sentence comprehension ability was the verbal working memory task. Conclusion: Syntactic structure and canonicity of word order elicited differential effects on the sentence comprehension ability of 5- and 6-year-old children, and verbal working memory capacity was strongly related to individual differences in understanding sentences with complex structures.
\end{abstract}

Keywords: Syntactic structures, Canonicity of word order, Sentence comprehension, Working memory
첫 낱말 산출 이후 어휘 폭발기를 거치면서 아동들은 낱말들을 병렬적으로 연결하는 문장 형태의 발화를 시작하게 된다. 그러다 가 점차 문법적 요소들을 익히게 되면서 낱말과 낱말 간 연결이 보 다 규칙적인 의미 있는 문장의 형태를 만들어 나가기 시작하게 되 는데(Kim, 2011), 이러한 구문 발달은 복잡한 문장을 이해하는 데 에도 중요한 기초가 된다. 문장을 정확히 이해하기 위해서는 행동 주(agent)가 누구이고 피동주(patient)가 누구인지, 그리고 무엇을 하고 있으며 그 방향은 어떤 것인지 문장을 구성하고 있는 성분인
낱말 간의 연결 관계를 잘 파악해야 한다(Wu et al., 2016). 이때 다 양한 단서를 사용하여 문장을 이해할 수 있는데, 언어발달 초기에 는 성인의 발화나 문장을 문맥이나 의미적 단서, 혹은 비언어적 단 서를 통해 이해하나, 점차 어순이나 조사, 시제 등의 문법 규칙 등을 습득하여 문장을 이해할 수 있게 된다(Kim, 2011). 즉 언어발달 단 계가 높아질수록 아동은 자신의 의미론적, 형태론적, 구문론적 지 식을 기반으로, 주어진 문장을 이해하는 데 필요한 전략을 사용하 게 된다. Strohner와 Nelson (1974)은 두 가지 통사 구조(능동과 피 
동)와 세 가지 수준의 의미적 개연성(probability)을 변수로 실험문 장을 구성하여 2-5세 아동의 문장이해능력을 검토하였다. 의미적 개연성은 일상적으로 가능한 진술(예: 아이가 공을 던진다), 일상적 으로 불가능한 진술(예: 거북이가 악어를 문다), 서술어를 제외한 다른 두 문장성분의 의미역을 바뀌도 의미적으로 성립 가능한 가 역적(reversible)인 진술(예: 늑대가 곰을 쫓는다)로 조작하였다. 그 결과, 3세까지는 일상에서 '일어날 수 있는 가능성 전략(probableevent strategy)'을 바탕으로 문장을 이해하는 데 반해, 4 세부터는 '행위자-대상-행위'의 어순 전략(word order strategy)을 사용하는 비율이 높아지며, 5 세에는 주로 문법적 단서를 사용하여 문장을 이 해함을 보였다. 한편 3-7세 아동들을 대상으로 문장이해능력을 살 펴본 국내의 선행연구(Hwang, 2003; Hwang \& Ahn, 2002)에서는 검사 문장에서 생물성 단서, 조사 단서, 어순 단서를 체계적으로 조 작함으로써 문장 이해에 있어서 의미론, 형태론, 통사론적 단서를 활용하는 발달적 양상을 살펴본 바 있다. 그 결과 3 세 아동들의 경 우 생물성(animacy) 단서의 활용도가 가장 높았으며, 연령이 높아 질수록 생물성 단서의 활용도는 낮아지고 조사 단서의 활용도가 높아져, 5 세 이후부터는 조사 단서를 생물성 단서보다 더 많이 사 용하는 것으로 나타났다. 또한 어순 단서는 모든 연령에서 활용도 가 가장 낮았으며, 특히 어순 단서로는 문장에서 나타난 첫 번째 명 사를 행위자로 해석하려는 경향이 두드러진 것으로 나타났다.

피동문은 능동문의 주어와 목적어의 관계가 일정한 문법적 법칙 에 의해 변형됨으로써, 피동문을 이해하기 위해서는 문장 내 행위 자와 대상자 간의 관계를 변형된 문법적 단서 및 단어의 형태, 또는 문맥적 단서를 통해 판단해야 하는 인지적 노력이 전제된다. 따라 서 아동의 피동문 발달을 검토해보는 것은 타인과의 관계를 이해 하는 인지발달 및 구문론 및 형태론 등 언어발달을 가늠해볼 수 있 다는 데에 의의가 있다고 할 것이다(Loeb, Pye, Richardson, \& Redmond, 1998). 영어에서는 능동문의 대상(theme)에 해당하는 목적 어가 행동주가 되면서 전치사 'by'가 추가되어 명사구가 만들어지 고 동사가 ‘be+과거분사'의 형태로 변형되면서 피동문이 만들어진 다. 한국어의 경우 능동사의 어간에 피동 접사(이, 히, 리, 기)가 붙 음으로써 피동사로 파생되거나 보조동사인 '-어지다'에 의해서도 피동문이 만들어질 수 있다(Kim, Lee, Kang, \& Nam, 2000). 또한 체언과 ‘되다', '받다', ‘당하다' 등의 통사적 결합에 의한 피동 표현, 혹은 피동의 의미를 갖는 개별 동사에 의한 피동 표현도 가능하다 (Lee, 2004). 하지만 문법론적인 관점을 엄격하게 적용한다면 피동 접사에 의한 피동 표현만이 피동 구문으로 인정될 수 있으며(Kim, 2007), 일반적으로 이러한 피동 접사에 의한 피동을 ‘형태론적 피 동'이라고 한다(Kim, 2014). 이때 능동문의 행동주에 있던 조사
‘이/가'가 ‘에게/한테’로 대치되어 부사구가 만들어지면서 능동문 이 피동문으로 변형된다. 이렇게 만들어진 피동문에서 영어의 경 우 명사구는 문장에서의 위치가 제한되어 있으나, 어순의 재배치가 비교적 자유로운 것으로 알려진 한국어의 경우 'A가 B에게 밀리다' 와 ‘B에게 A가 밀리다'가 모두 문법적으로 문제가 없는 문장으로 받아들여진다. 피동문은 한국어에 비해 영어권에서 상대적으로 늦 게 출현하는 경향이 있는데, 이는 한국어와 영어의 통사규칙 및 그 구조의 복잡성 차이를 이유로 들 수 있다(Cho, 1982). 즉 영어의 경 우에는 be동사 및 과거분사의 사용, by의 첨가, 명사의 위치 이동 등을 이해해야 하므로, 피동의 문법형태소(이, 히, 리, 기)의 첨가와 조사의 대치만을 고려하면 되는 한국어에 비해 복잡한 인지적 과 정을 거쳐야 하기 때문인 것으로 해석할 수 있다. 피동문 발달과 관 련된 국내의 선행연구들 중 5-73개월 아동 320명을 대상으로 자발 화를 수집하여 분석한 Pae (1995)의 연구에 의하면, 4 세 아동들은 보조동사인 '-어지다'로 피동형을 활발하게 탐색한다. 4 세 이전까 지는 피동 접사를 제한된 어휘에 사용하는데, 피동 접사를 오류 없 이 사용하게 되기까지는 약 4-5년의 시간이 걸린다고 하였다. $\mathrm{Ha}$ (1999)는 4-9세 아동 180명을 대상으로 피동문의 이해 및 표현능력 에 대해 연구했는데, 연령이 증가할수록 피동문의 이해와 표현능력 이 향상되었으며, 특히 4 세 집단과 다른 연령 집단 간의 정반응률 차이가 모두 유의하여 4 세 집단은 피동문의 이해 및 표현능력에 있 어서 다른 연령 집단과 상당한 차이가 있음을 밝혔다. 또한 18-59개 월 영유아 85명을 대상으로 한 Yi (2000)의 연구에 따르면 피동은 42-47개월 유아의 $12.5 \%, 48-59$ 개월 유아의 $6.3 \%$ 만이 산출한 것으 로 나타났음을 근거로 피동문은 48 개월이 지나야 획득된다고 하여, 18 개월, 30개월 유아에게도 피동문이 나타남을 밝힌 Cho (1982)의 사례가 일반적이지 않을 가능성을 제안했다.

한국어는 문장에서 서술어를 제외한 다른 문장 성분들의 배열 이 비교적 자유로운 어순을 갖는 것으로 알려져 있는데, 여기에는 조사가 중요한 역할을 한다. 즉, 조사가 격(case) 기능을 수행함으로 써 문장 내에서 다른 낱말들과의 문법적 관계를 나타내줄 수 있으 며, 이러한 조사를 사용하여 문장 성분들의 순서를 문법 규칙에 저 해되지 않게 비교적 자유롭게 변경할 수 있다고 알려져 있다(Shin, 2007). 그러나 서술어가 문장의 가장 마지막에 오지 않는 문장은 문법적으로 수용되기 어려우며, 서술어가 문장의 끝에 위치하는 문장과 동일한 수준으로 해석하기 어렵다는 의견이 있다(Sung, 1992). 따라서 서술어 후치의 고정 어순은 국어 어순의 가장 기본적 인 원리라고 할 수 있으며, 이 외 나머지 주어와 목적어, 주어와 보어 의 위치 이동이 자유로울 뿐이라는 것이다. 국내의 대다수 연구들 에서 국어가 ‘주어-목적어-서술어'의 SOV 어순을 갖는 언어임을 
전제로 하고 있으며, 국어학계의 선행연구(Kim, 2002)에서는 유형 론적 근거와 문법내적 근거를 바탕으로 국어는 동사가 문장에 맨 끝에 오며, 주어가 목적어에 선행하는 SOV 어순임을 주장한 바 있 다. 그렇다면 본 연구에서는 능동문에서는 주어와 목적어의 위치 만을 변경하고, 피동문에서는 행동주와 피동주를 조사를 활용하 여 표현하되 어순을 조작하여 문장이해능력을 평가함으로써, 한 국어의 어순 규범성 여부를 확인하고 아동의 문장이해 전략을 검 토해보고자 한다. 한국어가 어순에서 자유롭다면, 어순에 따른 문 장이해능력의 차이가 유의하지 않을 것이며, 아동은 어순 전략이 아닌 다른 형태론 및 통사론적 전략을 사용할 것으로 예측할 수 있 다. 3-7세 아동이 문장을 이해할 때 의미론, 형태론, 통사론적 단서 를 활용하는 양상을 살펴본 국내의 선행연구(Hwang, 2003; Hwang \& Ahn, 2002)에서는 3어절의 검사 문장에서 동작동사 외의 명사 를 생물명사와 무생물명사로 구성함으로써 생물성 단서가 문장이 해에 미치는 영향을 검토하였다. 이와 달리 본 연구에서는 동사의 행위자가 되는 명사구는 '노랑이', '파랑이', '검정이'의 색깔로 상징 화하여 행위자들에 중성적인 특징을 부여함으로써 문장 이해에서 의미적 단서인 생물성 단서의 영향을 최소화하고 형태론 및 통사 론적 단서의 영향을 살펴보고자 하였다.

본 연구에서는 문장이해능력을 평가하기 위하여 다음과 같은 세 가지 유형의 문장을 사용하였다. 첫 번째로 능동문-2항 동사 문 형은 주어와 목적어 2 개의 논항이 필요한 동사로 이루어진 문장이 며, 두 번째로 능동문-3항 동사 문형은 주어와 목적어, 그리고 부사 구 3 개의 논항과 동사로 이루어진 문장이다. 마지막으로 피동문은 능동문-2항 동사 문형과 동일한 3어절로 구성하였다. 정리하자면, 본 연구에서는 대상 아동들의 문장이해능력을 문장의 복잡성 수 준과 길이에 따라 평가하고자 하였다(Sung, 2015). 즉, 대상 아동들 의 문장이해능력을 평가함에 있어서 능동문-2항과 능동문-3항의 통사 구조에 따른 문장길이 효과 및 피동문의 명사구 이동에 따른 복잡성 효과를 동시에 검토하고자 하였다. 이때 문장의 복잡성 수 준이 높을수록, 또는 문장의 길이가 길수록 대상 아동들이 문장을 처리하는 데 드는 인지적 부담(load)이 커질 것을 예상할 수 있는 데, 여기에는 작업기억(working memory)이 주요한 자원으로 작용 한다(Barrouillet \& Camos, 2001; Caplan \& Waters, 1999; Just \& Carpenter, 1992; King \& Just, 1991; Waters \& Caplan, 2004). 작업 기억은 정보의 저장과 처리를 동시에 수행하는 인지적 자원이라고 할 수 있는데(Just \& Carpenter, 1992), 이러한 이론에 따르면 일반 적으로 개인이 보유한 작업기억 용량은 한정되어 있으며 따라서 각 개인은 자신이 보유한 작업기억 용량 내에서 저장과 처리 간 교환 (trade-off) 과정을 거치면서 정보를 처리한다. 그러므로 복잡성이
높은 인지처리 과제를 수행하는 경우 처리에 사용되는 인지적 부 담이 높아진다면 저장에 사용할 수 있는 용량이 작아지게 된다. 또 한 통사적 복잡성이 높은 언어처리를 요하는 과제의 경우 대상자 의 작업기억 용량이 충분하지 않다면 문장 이해에 어려움을 보이 게 될 것임을 예측해볼 수 있다(Magimairaj \& Montgomery, 2012). 작업기억과 문장이해력 간의 간의 관계를 검토한 많은 선행연구들 이 있는데(Caplan \& Waters, 1999; Magimairaj \& Montgomery, 2012; Montgomery, 2000; Montgomery \& Evans, 2009; Montgomery, Magimairaj, \& O'Malley, 2008), 이러한 연구들에서는 작업기 억이 언어처리에 미치는 영향을 강조한다. 언어를 습득하면서 통사 론 및 담화 구조를 구축하기 위해서는 단어와 음절 등 수많은 언어 적 단위들을 서로 연결시켜야 하는데, 이런 과정에서 언어의 구조 적 특징을 파악하고 분석해내는 데에 작업기억이 중요한 역할을 하 기 때문이다(Marton \& Schwartz, 2003). 본 연구는 앞에서 검토한 바와 같이 문장이해 과정에서 의미적 단서의 영향을 최소화하고 형태론 및 통사론적 단서가 미치는 영향을 살펴보되 문장의 복잡 성 수준을 통사 구조와 문장 길이로 체계화하여 검토해보고자 하 며, 문장의 복잡성 수준에 따른 이해능력을 작업기억이 예측해줄 수 있는지 알아보고자한다.

본 연구의 연구질문은 다음과 같다.

1) 통사 구조(능동문-2항, 능동문-3항, 피동문)와 어순 규범성(규 범 어순, 비규범 어순)에 따른 문장이해능력에 차이가 있는가?

2) 문장이해능력을 유의하게 예측하는 작업기억 과제의 유형은 무엇인가?

\section{연구방법}

\section{연구대상}

본 연구는 경기권에 거주하는 만 5-6세( $\mathrm{M}=72.72$ 개월, $\mathrm{SD}=5.539)$ 의 일반아동 18 명(남아 5 명, 여아 13 명)을 대상으로 하였다. 연구에 참여한 모든 아동은 (1) 한국 카우프만 아동용 지능검사(Korean Kaufman Assessment Battery for Children, K-ABC; Moon \& Byun, 2003) 결과 비언어성 지능지수가 85 (-1 SD) 이상으로, (2) 취학전 아 동의 수용언어 및 표현언어 발달 척도(Preschool Receptive Expressive Language Scale, PRES; Kim, Sung, \& Lee, 2011) 결과 수용언 어 발달연령과 표현언어 발달연령이 모두 생활연령과 1년 이상 차 이 나지 않으며, (3) 부모 또는 교사에 의해 시각, 청각 및 신경, 기타 정서장애가 없는 것으로 보고된 아동들로 선정하였다. 본 연구에 참여한 대상자의 구체적인 정보는 Table 1에 제시하였다. 
Table 1. Participants' characteristics

\begin{tabular}{|c|c|c|c|c|c|}
\hline \multirow{2}{*}{ ID } & \multirow{2}{*}{ Gender } & \multirow{2}{*}{$\begin{array}{l}\text { Age } \\
\text { (mo) }\end{array}$} & \multicolumn{2}{|c|}{ PRES } & \multirow{2}{*}{$\mathrm{K}-\mathrm{ABC}$} \\
\hline & & & Receptive & Expressive & \\
\hline 1 & $\mathrm{~F}$ & 63 & 46 & 48 & 110 \\
\hline 2 & $\mathrm{~F}$ & 65 & 56 & 56 & 115 \\
\hline 3 & M & 68 & 58 & 50 & 117 \\
\hline 4 & $F$ & 68 & 54 & 54 & 108 \\
\hline 5 & $M$ & 69 & 48 & 42 & 103 \\
\hline 6 & $\mathrm{~F}$ & 69 & 46 & 56 & 101 \\
\hline 7 & $\mathrm{~F}$ & 70 & 44 & 48 & 106 \\
\hline 8 & $\mathrm{~F}$ & 71 & 58 & 44 & 101 \\
\hline 9 & $\mathrm{~F}$ & 72 & 50 & 58 & 95 \\
\hline 10 & $\mathrm{~F}$ & 72 & 56 & 54 & 103 \\
\hline 11 & $M$ & 74 & 60 & 52 & 99 \\
\hline 12 & $\mathrm{~F}$ & 74 & 56 & 56 & 89 \\
\hline 13 & $F$ & 75 & 56 & 56 & 110 \\
\hline 14 & $M$ & 76 & 60 & 56 & 104 \\
\hline 15 & $\mathrm{~F}$ & 79 & 56 & 56 & 109 \\
\hline 16 & $\mathrm{~F}$ & 80 & 50 & 54 & 113 \\
\hline 17 & $M$ & 82 & 54 & 58 & 91 \\
\hline 18 & $\mathrm{~F}$ & 82 & 60 & 58 & 100 \\
\hline
\end{tabular}

$\mathrm{F}=$ female; $\mathrm{M}=$ male; PRES = Preschool Receptive Expressive Language Scale (Kim, Sung, \& Lee, 2011); K-ABC=Korean-Kaufman Assessment Battery for Children (Moon \& Byun, 2003).

\section{실험과제}

\section{문장이해검사(Sentence Comprehension Test, SCT)}

본 검사는 통사 구조와 어순 규범성에 따른 문장이해능력을 살 펴보는 과제로, 노년층을 대상으로 한 선행연구(Sung, 2015)에서 사용된 과제를 본 연구의 대상 연령에 맞게 수정하여 사용하였다. 본 과제는 피험자의 통사처리(syntactic processing) 능력을 알아보 기 위한 과제로서, 3 개의 통사 구조(능동문-2항, 능동문-3항, 피동 문)에서 규범 어순 6개, 비규범 어순 6개씩 문항을 구성하여 총 36 개의 문항으로 제작되었다. 의미 단서가 문장이해에 미치는 영향을 최소화하기 위하여 동사의 행위자는 '노랑이/파랑이/검정이'로 상 징화하였으며, 각 문항마다 문장의 내용과 일치하는 목표 그림(target picture)과, 제시된 문장과 의미역이 대치된 통사오류 그림(syntactic foil picture)이 함께 제시되었다. 본 연구에서는 Sung (2015) 의 과제를 활용하되, 대상 연령을 고려하여 취학전 아동 대상 공식 검사인 PRES (Kim et al., 2011)와 마찬가지로 제시 문항의 어미를 '해요체'로 변경하였으며, 수여격조사 ‘한테'가 3세 후반기 아동의 $60 \%$ 이상에게서 나타난다는 선행연구(Kwon \& Jeong, 2000)를 참 고하여 ‘에게’를 ‘한테’로 변경하였다. 연구 대상의 연령을 고려하여 개정된 과제는 정확한 반응 측정을 위하여 E-prime 2.0 을 사용하 여 다시 제작하였다. 각 문항의 그림이 컴퓨터 화면에 나타나고 500 $\mathrm{ms}$ 후 목표 문장이 음성파일로 제시되면, 피험자는 이를 듣고 문항 과 일치하는 그림을 키보드의 버튼을 눌러서 고르도록 하였다. 아 동이 버튼을 누르면 컴퓨터 화면의 중앙에 응시점(+)이 나타나도록 하였으며, $200 \mathrm{~ms}$ 이후 다음 문항이 제시되었다. 이때 아동의 반응 시간이 본인 평균의 \pm 3 표준편차인 경우 극단치(outlier)로 간주하 여 분석에서 제외하였다(DeDe, Caplan, Kemtes, \& Waters, 2004). 본 검사에서 사용된 문장이해검사의 문장유형별 목표문항과 그림 의 예는 Appendixes 1 과 2에 제시하였다.

\section{작업기억 과제}

문장이해와 작업기억 간의 관계를 검토한 선행연구들에서는 주 로 음운작업기억(Montgomery, 1995; Montgomery \& Evans, 2009), 문장폭 기억(Magimairaj \& Montgomery, 2012; Marton \& Schwartz, 2003; Montgomery \& Evans, 2009) 등 언어성 작업기억 과제를 중 심으로 살펴보았다. Waters와 Caplan (2003)에 의하면 작업기억을 평가할 때 작업기억 과제를 세 가지 이상 사용해야 안정성 및 신뢰 도가 확보되는 바, 본 연구에서는 다수의 선행연구들에서 언어성 작업기억을 측정하기 위하여 사용된 과제들을 중심으로 작업기억 을 평가하되, 비언어성 작업기억의 영향도 동시에 검토해보기 위하 여 다음과 같은 다섯 가지의 작업기억 과제를 사용하였다.

\section{비단어 따라말하기(Nonword Repetition)}

비단어 따라말하기는 친숙하지 않은 음운정보를 순간적으로 기 억했다가 회상해내는 과제로, 음운작업기억을 측정하는 도구로 알 려져 있다(Gathercole, 1995). 본 연구에서는 단어 유사성이 낮으면 서 음소전이확률(phonotactic probability)이 높은 비단어 목록을 사용한 선행연구(Oh \& Yim, 2013)의 과제를 사용하였는데, 2음절 (1단계)부터 6음절(5단계)까지의 비단어 목록을 피험자에게 들려 주고 즉시 그대로 따라 말하게 하였다. 각 단계는 4 문항씩 총 20 개 문항으로 구성되었으며, 2음절 4 개 문항부터 시작하여 6음절 4 개 문항까지 순차적으로 제시되었다. 모든 연구 대상자는 중지점 없이 20 개의 모든 문항을 수행하도록 하였다. 비단어 자극은 음성파일 로 제시되었으며, 연구 대상 아동에게 컴퓨터를 통해 들리는 음성 을 ‘앵무새처럼' 따라 말하도록 지시하였다. 본 연구에서는 단어 수 준 채점방식이 음절 수준 채점방식에 비해 비단어 따라말하기 과 제의 음절 길이에 따른 수행력 변화를 더욱 민감하게 반영한다는 선행연구(Hwang, 2015)를 참고하여 단어 수준 채점방식을 적용하 였다. 즉, 아동이 문항에서 제시된 음절의 모든 음소에서 정반응한 경우 1 점, 한 개의 음소라도 틀리게 반응하는 경우 0 점으로 처리하 여, 정반응한 문항의 수를 총점으로 계산하였다. 


\section{숫자 거꾸로 따라말하기(Backward Digit Span)}

숫자 거꾸로 따라말하기 과제는 피험자에게 숫자를 그대로 따라 말하도록 했던 선행연구(Yim, Kim, \& Yang, 2015)의 과제를 수정 하여 사용하였다. Yim 등(2015)의 연구에서는 숫자가 2개(1단계) 부터 7개(6단계)까지 나열된 문항을 연구 대상자에게 들려주면서 그대로 따라 말하도록 지시하였다. 1 단계부터 순차적으로 제시되 었으며, 회상해야 하는 숫자의 목록은 단계별로 두 문항씩으로 구 성되었다. 즉, 숫자 2 개로 구성된 1단계 두 문항, 숫자 세 개로 구성 된 2단계 두 문항 등이 순차적으로 제시되어 문항별로 정오를 판단 하여 총점을 산출하였다. 본 연구에서는 입력된 청각 정보를 순간 적으로 저장했다가 바로 인출하기보다는, 음운기억을 '조작'하게 함으로써 중앙집행기의 기능도 활성화하도록(Gathercole, Pickering, Ambridge, \& Wearing, 2004) 연구 대상자에게 청각적으로 제 시되는 숫자의 목록을 거꾸로 따라말하게 하였다. 또한 각 단계에 한국판 웩슬러 아동용 지능검사(Korean Wechsler Intelligence Scale for Children, K-WISC; Kwak, Moon, \& Oh, 2011)의 숫자 거 꾸로 따라하기 소검사의 문항 한 개씩을 추가하여 1 단계부터 6 단계 까지 각 단계의 문항수를 3 개로 수정하여 총 문항의 수는 18 문항 으로 하였고, K-WISC를 참고하여 한 단계의 모든 문항에서 오반 응한 경우를 중지점으로 하였다. 문항별로 하나의 숫자라도 틀렸을 경우 0 점, 모든 숫자를 정확하게 거꾸로 회상했을 경우 1 점을 부과 하였으며, 중지점까지의 정반응한 문항의 수로 총점을 산출하였다

\section{경쟁 언어 처리 과제(Competing Language Processing Task)}

경쟁 언어 처리 과제는 연구 대상자에게 문장의 의미에 대한 정 오 판단과 동시에 마지막 단어를 회상하여 산출하게 함으로써 처 리와 저장의 인지적 과업을 동시에 수행해야 하는 작업기억 과제로 서(Weismer, Evans, \& Hesketh, 1999), 본 연구에서는 선행연구 (Yim et al., 2015)의 과제를 사용하였다. 3 어절의 문장들이 1개(1단 계)부터 6개(6단계)까지 음성파일로 제시되며, 연구 대상자는 각 단계에서 문장이 제시될 때마다 정오판단을 하고, 모든 문항을 다 듣고 난 후 마지막 단어를 회상하도록 하였다. 즉, 1 단계에서는 1 개 의 문장을 듣고 정오판단 후 마지막 단어 회상을, 2 단계에서는 각 문장을 들을 때마다 정오판단을 하고 '각 문장의 마지막 단어는 무 엇이었나요?'라는 음성이 제시된 후 두 문장의 마지막 단어를 회상 하여 산출하도록 하였다. 각 단계는 두 세트씩으로 구성되어 총 문 항수는 42 개이며, 정오판단과 마지막 단어 회상이 각각 42 점씩 총 점 84점으로 채점되었다. 이때 2 개 이상의 문장을 들려줄 때에는 제시된 문장의 순서와 상관 없이 아동이 문장의 마지막 단어를 바 르게 회상하였다면 정반응으로 처리하였다. 예를 들어 3 단계에서
'연필로 이를 닦는다', '돼지는 날씬한 동물이다', '눈은 여름에 내린 다'의 문장을 모두 듣고 난 후, '닦는다', '동물이다', '내린다'를 순서 에 상관 없이 모두 정확하게 회상하였다면 3점을 부여하였다.

\section{문장 따라말하기(Sentence Repetition)}

문장 따라말하기 과제는 언어장애를 진단하는 데 있어서 효과적 인 도구이자(Conti-Ramsdem, Botting, \& Faragher, 2001) 작업기 억을 측정하는 과제로 알려져 있다(Alloway, Gathercole, Willis, \& Adams, 2004). 본 연구에서는 선행연구(Ahn \& Kim, 2000)에서 사 용한 문장 따라말하기(Sentence Repetition) 과제를 실시하였다. 본 과제는 문장 길이(3어절, 5 어절)와 문장 구조(단문, 접속복문, 내포 복문) 조건으로 구문적 난이도를 구성하였으며, 연구 대상 아동에 게 컴퓨터를 통해 음성파일로 제시되는 모든 문장 자극을 '앵무새 처럼 그대로 따라 말하게 하였다. 문장 자극은 3어절 단문(예: 머리 를 샴푸로 감아요) 9문항, 5 어절 단문(예: 친구가 작은 가위로 종이 를 잘라요) 9문항, 5 어절 접속문(예: 친구가 배고파서 밥을 빨리 먹 어요) 9 문항, 5 어절 내포문(예: 아빠가 청소를 하는 엄마를 불러요) 8문항, 총 35문항으로 구성되었다. 5-6세 아동을 대상으로 한 국내 의 선행연구(Hwang, 2012)에 의하면 문장 따라말하기 과제의 문 장 단위 채점 결과가 단어 단위 채점 결과에 비해 다른 언어검사와 의 상관관계가 높고 단순언어장애의 진단정확도가 높은 것으로 나 타난 바, 본 연구에서도 문장 단위 점수 산출 방식을 채택하였다. 즉, 제시된 각 문장을 정확하게 따라 말한 경우 1 점, 어느 한 부분이 라도 틀린 경우 0 점을 부과하여 정반응한 문항의 수로 총점을 산 출하였다.

\section{매트릭스(Matrix)}

구어 반응이 요구되지 않는 작업기억 과제로서 선행연구(Yim et al., 2015)에서 사용된 매트릭스(Matrix) 과제를 실시하였다. 이 과 제는 컴퓨터에 제시되는 검정색의 $3 \times 3$ 매트릭스에 주황색 불이 점등되면, 연구 대상자가 그 순서를 기억했다가 역순으로 회상하는 과제이다. 연구 대상 아동이 '거꾸로'의 의미를 정확히 이해하는지 를 먼저 판단하고 연습문제를 통해 과제를 이해했음을 확인한 후 본 문항을 실시하였다. 9 개의 빈 칸 중 점등되는 칸의 수는 2개(1단 계)부터 5 개(4단계)까지 순차적으로 많아지며, 1 단계와 2 단계가 각 각 4 문항씩, 3 단계와 4 단계가 각각 5 문항씩으로 구성되어 있다. 연 구 대상 아동들은 9개 칸으로 이루어진 매트릭스에 $500 \mathrm{~ms}$ 간격으 로 점등되는 주황색 불의 위치를 기억했다가 역순으로 회상하여 손가락으로 가리키도록 하였다. 각 단계의 모든 문항에서 오반응하 였을 때를 중지점으로 하였으며, 정반응한 문항에 1점씩 부과하여 
중지점까지의 정반응한 문항의 개수로 총점을 계산하였다.

\section{자료분석}

통사 구조(능동문-2항, 능동문-3항, 피동문)와 어순 규범성(규범 어순, 비규범 어순)에 따른 문장이해능력 차이를 검토하기 위하여 $3 \times 2$ 반복측정 이원분산분석(repeated two-way ANOVA)을 실시 하였으며, 단일표본 $t$-검정(one sample $t$-test)을 실시하여 과제의 각 하위유형별 수행력이 우연수준(chance level)보다 유의하게 높은지 검토하였다. 또한 탐색적 요인분석(exploratory factor analysis)을 실시하여 다섯 가지의 작업기억 과제가 몇 개의 공통요인으로 분류 될 수 있는지 검토하였으며, 추출된 요인을 기반으로 문장이해능력 을 유의하게 설명해주는 작업기억 과제가 무엇인지 알아보기 위하 여 단계적 중다회귀분석(stepwise multiple regression)을 실시하였 다. 모든 통계 분석은 SPSS 23.0 을 사용하였다.

\section{연구결과}

\section{통사 구조와 어순 규범성에 따른 문장이해능력의 차이}

문장이해검사의 통사 구조와 어순 규범성에 따른 6 가지 각 하위 유형별 정반응률에 대한 기술통계 결과는 Table 2 와 같다. 모든 통 사 구조에서 비규범 어순에 비해 규범 어순의 정반응률이 높았으 며, 규범 어순에서는 능동문-2항(M=91.67\%, $\mathrm{SD}=8.57)$, 능동문-3 항 $(\mathrm{M}=82.41 \%, \mathrm{SD}=17.59)$, 피동문 $(\mathrm{M}=59.26 \%, \mathrm{SD}=27.55)$ 의 순 서로 정반응률이 높았으나, 비규범 어순에서는 능동문-3항 $(\mathrm{M}=$ $56.48 \%, \mathrm{SD}=30.86)$, 피동문( $\mathrm{M}=57.41 \%, \mathrm{SD}=23.02)$, 능동문-2항 $(\mathrm{M}=57.41 \%, \mathrm{SD}=23.02)$ 의 순서로 정반응률이 높게 나타났다.

통사 구조와 어순 규범성에 따른 문장이해검사 수행력에 차이가 있는지 알아보기 위하여 반복측정 이원분산분석(two-way repeated ANOVA)을 실시하였으며, 그 결과 통사 구조의 주효과가 통계 적으로 유의하였다 $\left(F_{(2,34)}=6.752, p<.005\right)$. 이에 따라 Bonferroni 사후검정을 실시한 결과 능동문-2항과 피동문, 능동문-3항과 피동 문 간의 차이가 통계적으로 유의하여( $p<.05)$, 피동문에 대한 수행

Table 2. Percent accuracy of the sentence comprehension task for each condition

\begin{tabular}{lcl}
\hline Condition & \multicolumn{1}{c}{ Canonical } & \multicolumn{1}{c}{ Non-canonical } \\
\hline Active-2 place & $91.67 \pm 8.57(83.33-100)$ & $56.48 \pm 30.86(0-100)$ \\
Active-3 place & $82.41 \pm 17.59(33.33-100)$ & $67.59 \pm 21.75(33.33-100)$ \\
Passive & $59.26 \pm 27.55(16.67-100)$ & $57.41 \pm 23.02(16.67-100)$ \\
\hline
\end{tabular}

Values are presented as mean $\pm S D$ (range).

Active-2 place =active sentence with 2-place verbs; Active-3 place = active sentence with 3-place verbs; Passive $=$ passive sentence.
력이 다른 두 유형의 문장 구조에 비해 유의하게 낮은 것으로 나타 났다. 어순 규범성의 주효과 또한 유의한 것으로 나타나 $\left(F_{(1,17)}=\right.$ $24.727, p<.001)$, 규범 어순의 수행력이 비규범 어순의 수행력에 비 해 유의하게 높음을 확인하였다. 이차상호작용 또한 통계적으로 유의하였던 바 $\left(F_{(2,34)}=5.797, p<.01\right)$, MMATRIX를 사용한 사후검 정을 실시하였다. 그 결과, 능동문-2항과 능동문-3항 간 규범 어순 과 비규범 어순의 정반응률 차이 $\left(F_{(1,17)}=3.971, p>.05\right)$ 와 능동문-3 항과 피동문 간 규범 어순과 비규범 어순의 정반응률 차이 $\left(F_{(1,17)}=\right.$ $2.340, p>.05)$ 는 통계적으로 유의한 차이가 없었으나, 능동문-2항 과 피동문 간 규범 어순과 비규범 어순의 정반응률의 차이는 통계 적으로 유의한 차이가 있는 것으로 나타났다 $\left(F_{(1,17)}=9.563, p<.05\right)$. 즉, 이차상호작용은 규범 어순과 비규범 어순의 수행력 차이가 능 동문-2항에서보다 피동문에서 유의하게 작은 것에서 기인한 것으 로 나타났다. 이에 대한 그래프는 Figure 1에 제시하였다.

한편 문장이해검사에 대한수행력이 우연수준(chancelevel=50\%) 보다 유의하게 높은지 검토하기 위하여 단일표본 $t$-검정(one sample $t$-test)을 실시하였다. 그 결과, 능동문-2항의 규범 어순 $\left(t_{17}=20.616\right.$, $p<.001)$ 과 능동문-3항의 규범 어순 $\left(t_{17}=7.815, p<.001\right)$, 그리고 능 동문-3항의 비규범 어순 $\left(t_{17}=3.432, p<.005\right)$ 의 정반응률은 우연수 준보다 유의하게 높은 것으로 나타났으나, 능동문-2항의 비규범 어 순과 피동문의 규범 및 비규범 어순의 정반응률은 우연수준과 통 계적으로 유의한차이가 나타나지 않았다 $\left(t_{17}=1.767, p>\right.$.05) (Table 3).

\section{문장이해능력에 대한 작업기억의 설명력}

본 연구에서 실시한 다섯 가지 작업기억 과제의 기술통계 결과는 Table 4 와 같다. 본 연구에서는 다섯 가지의 작업기억 과제가 몇 개

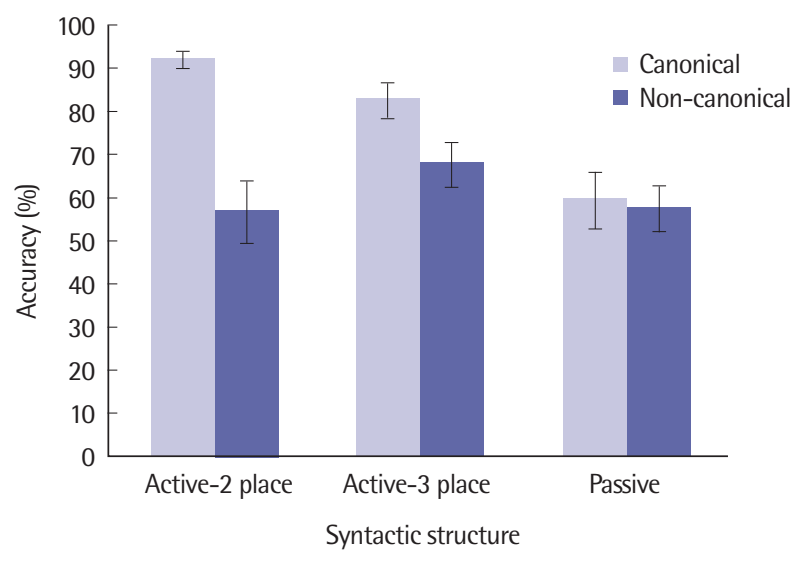

Figure 1. Performance on sentence comprehension task as a function of syntactic structure and canonicity.

Active-2 place=active sentence with 2-place verbs; Active-3 place=active sentence with 3-place verbs; Passive= passive sentence. 
Table 3. Results from one-sample $t$-test for each condition

\begin{tabular}{lllrc}
\hline Condition & & Accuracy & \multicolumn{1}{c}{$t$} & $p$-value \\
\hline Active-2 place & Canonical & $91.67(8.57)$ & 20.616 & $.000^{*}$ \\
& Non-canonical & $56.48(30.86)$ & .891 & .385 \\
\multirow{2}{*}{ Active-3 place } & Canonical & $82.41(17.59)$ & 7.815 & $.000^{*}$ \\
& Non-canonical & $67.59(21.75)$ & 3.432 & $.003^{* *}$ \\
Passive & Canonical & $59.26(27.55)$ & 1.426 & .172 \\
& Non-canonical & $57.41(23.02)$ & 1.365 & .190 \\
\hline
\end{tabular}

Values are presented as mean (SD).

Active-2 place =active sentence with 2-place verbs; Active-3 place $=$ active sentence with 3-place verbs; Passive $=$ passive sentence .

${ }^{*} p<.001,{ }^{* *} p<.005$.

Table 4. Descriptive statistics of working memory tasks

\begin{tabular}{lr}
\hline Task & \multicolumn{1}{c}{ Value } \\
\hline Nonword repetition & $14.67(2.169)$ \\
Digit span & $4.33(1.328)$ \\
CLPT & $53.83(6.688)$ \\
Matrix & $7.61(2.953)$ \\
Sentence repetition & $31.78(3.719)$
\end{tabular}

Values are presented as mean (SD).

CLPT = Competing Language Processing Task.

의 공통된 인지적 요인으로 분류될 수 있는지를 검토하기 위하여 탐색적 요인분석(exploratory factor analysis)을 실시하였다. 요인추 출 방법으로는 주성분 분석(principle component analysis)을 사용 하였으며, 요인회전은 프로맥스(promax) 회전을 실시하였다. 그 결 과 고유값(eigenvalue)이 1보다 큰 요인이 3개 추출되었으며, 요인 1 은 총분산의 $36.465 \%$ (고유값 $=1.823$ ), 요인 2는 $27.663 \%$ (고유값= 1.383 ), 요인 3은 $22.437 \%$ (고유값 $=1.122$ )를 설명하는 것으로 나타 나, 세 가지 요인이 전체 총분산의 $86.565 \%$ 의 설명력을 갖는 것으 로 나타났다(Table 5). 요인 적재량(factor loading) .5 이상을 기준 으로 적용하여 각 요인을 구성한 과제들을 검토한 결과, 요인 1은 비단어 따라말하기, 숫자 거꾸로 따라말하기, 경쟁 언어 처리 과제 의 3 개 과제가 하나의 요인으로 추출되었다. 비단어 따라말하기, 숫 자 거꾸로 따라말하기, 경쟁 언어 처리 과제는 모두 청각적으로 입 력된 언어적 정보를 일시적으로 저장하고 처리하는 구어 작업기억 (verbal working memory)과 관련 있는 과제로서(Conway et al., 2005; Dollaghan \& Campbell, 1998; Mainela-Arnold \& Evans, 2005; Montgomery \& Evans, 2009), 본 연구에서는 이 세 가지 과제를 구 어 작업기억 과제로 명명하고 세 개 과제의 총점을 구어 작업기억 과제 점수로 자료 분석에 사용하였다. 요인 2는 매트릭스 과제, 요인 3 은 문장 따라말하기 과제로 각각 한 개씩의 요인으로 추출된 바, 본 연구에서는 과제 이름을 요인 이름으로 그대로 사용하기로 하였다.
Table 5. Factor loadings and communalities

\begin{tabular}{lcccc}
\hline Working memory task & Factor 1 & Factor 2 & Factor 3 & Communality \\
\hline Nonword repetition & .927 & -.045 & .361 & .853 \\
Digit span & .786 & .376 & -.213 & .867 \\
CLPT & .550 & -.632 & -.226 & .811 \\
Matrix & .190 & .906 & -.051 & .859 \\
Sentence repetition & .156 & .005 & .990 & .938 \\
Eigenvalue & 1.823 & 1.383 & 1.122 & - \\
\% of variance & 36.465 & 27.663 & 22.437 & - \\
Cumulative \% & 36.465 & 64.129 & 86.565 & - \\
\hline
\end{tabular}

Oblique promax rotation method was used.

CLPT = Competing Language Processing Task.

Factor loadings over .5 are indicated in bold.

Table 6. Results of stepwise regression analysis

\begin{tabular}{|c|c|c|c|c|c|c|}
\hline Condition & Predictor & $\begin{array}{c}\text { Unstan- } \\
\text { dardized } \\
\beta\end{array}$ & SE & $\begin{array}{c}\text { Standard- } \\
\text { ized } \beta\end{array}$ & $\begin{array}{c}R^{2} \text { (adjust- } \\
\text { ed } R^{2} \text { ) }\end{array}$ & $p$-value \\
\hline Total & Verbal WM & .076 & .034 & .488 & $.238(.190)$ & .040 \\
\hline Passive & Verbal WM & .041 & .018 & .496 & $.246(.199)$ & .036 \\
\hline
\end{tabular}

Total $=$ total scores of SCT; Passive $=$ passive sentence .

본 연구에서는 문장이해능력을 설명해주는 작업기억 과제를 알 아보기 위하여 문장이해검사의 총점, 그리고 통사 구조 및 어순 규 범성의 범주별로 총점을 구하여 각각을 종속변수로 한 단계적 회 귀분석(stepwise multiple regression)을 실시하였다. 그 결과, 문장 이해검사의 총점을 유의하게 설명해주는 작업기억 과제는 구어 작 업기억 과제 $\left(F_{(1,16)}=4.998, p<.05\right)$ 인 것으로 나타났으며, 통사 구조 중 피동문 문항의 총점을 유의하게 설명해주는 작업기억 과제도 구어 작업기억 과제 $\left(F_{(1,16)}=5.212, p<.05\right)$ 인 것으로 나타났다(Table 6). 통사 구조 중 능동문-3항, 능동문-3항, 그리고 어순 규범성의 두 하위 영역인 규범 어순, 비규범 어순의 총점을 유의하게 설명해 주는작업기억 과제는 없었다.

\section{논의 및 결론}

본 연구는 통사 구조 및 어순 규범성이 5-6세 아동의 문장이해능 력에 미치는 영향을 알아보고, 문장이해능력을 작업기억이 설명할 수 있는지 검토하고자 하였다. 그 결과, 피동문의 정반응률이 능동 문-2항 및 능동문-3항에 비해 유의하게 낮아, 피동문에 대한 이해 력이 능동문에 비해 낮은 것으로 나타났다. 4-9세의 일반 아동을 대상으로 한 국내의 선행연구(Ha, 1999)에 의하면 모든 연령 집단 에서 피동문의 이해는 표현에 비해 수행력이 낮은 것으로 나타났 다. 과제의 정반응률을 살펴보면 9 세가 되면 피동문의 이해는 $90 \%$ 
에 가까운 수준에 이르지만, 피동문의 표현은 $80 \%$ 를 근소하게 넘 는 정도인 것으로 나타났다. 5-6세의 경우에는 피동문의 이해는 약 $75 \%$ 수준, 표현은 약 $60 \%$ 전후인 것으로 나타나, 능동문에 비해 피 동문이 늦은 시기까지 발달함을 밝혔다. 또한 피동문 표현에 있어 서도 문법형태소('이', ‘히', '리', '기')를 사용한 피동문이 4세 이전에 는 몇 개의 제한된 어휘에서 한정적으로 사용되다가 주체와 객체에 대한 완전한 이해가 확립된 이후 피동문의 사용이 안정화됨을 검 토한 선행연구가 있다(Pae, 1995). 선행연구들을 고려해 볼 때 본 연 구의 대상인 5-6세 아동은 아직 피동문의 발달이 성숙하지 않은 시기로서, 이는 단일표본 $t$-검정 결과 피동문의 정반응률이 우연수 준과 통계적으로 유의한 차이가 없었다는 점에서도 확인해볼 수 있다. 다시 말해, 본 연구의 결과는 다수의 선행연구(Ha, 1999; Maratsos, Becker, \& Chalkley, 1985; Pae, 1995; Slobin, 1966)들과 마찬 가지로 피동문의 수행력이 능동문에 비해 낮음을 확인하였으며, 이는 본 연구의 대상 아동들의 연령이 피동문의 이해 및 표현의 발 달단계에 있기 때문인 것으로 보인다.

기술통계 결과 모든 통사 구조 조건에서 규범 어순의 수행력이 비규범 어순의 수행력에 비해서 높게 나타났는데, 이는 주격조사가 문장의 첫 번째 항에 위치했을 때의 문장 이해력이 주격조사가 문 장의 두 번째 항에 위치했을 때에 비해 높았음을 의미한다. 즉, 본 연구의 결과 5-6세 아동들은 통사 구조와 무관하게 주격조사가 문 두에 위치한 문장을 더 잘 이해하는 것으로 나타나, 어순 규범성이 문장 이해에 영향을 미침을 확인하였다. 이러한 연구 결과는 한국 어가 '제한적으로' 자유로운 어순을 갖는 언어라는 의견(Shin, 2007; Sung, 1992)을 지지하며, 대상 아동들이 문장을 이해하는 데 있어 문장에서 먼저 출현하는 명사구를 동사의 행위자(agent)로 간주하 는 어순전략(agent-first strategy) (Cho, 1982; Evans, 2002)을 사용 하고 있음을 의미한다. 또한 통사 구조와 어순 규범성의 이차상호 작용이 유의한 것으로 나타나, 어순 규범성이 문장 이해력에 미치 는 영향이 통사 구조에 따라 다르게 나타남을 확인하였다. 피동문 의 경우 능동문-2항에 비해 규범 어순과 비규범 어순의 수행력 차 이가 크지 않았는데, 이는 앞에서 지적한 바와 같이 피동문이 계속 발달하고 있는 연구 대상 아동들의 연령 효과로 설명할 수 있다. 즉, 피동문에서는 규범 어순이 문장 이해력에 미치는 촉진적 효과가 다른 두 통사 구조와 달리 충분히 나타나지 않았으며, 이러한 결과 는 연구 대상 아동들이 피동문 발달이 성숙하지 않은 시기이기 때 문인 것으로 판단된다. 또한 규범 어순에서도 수행력이 우연 수준 으로 나타난 피동문을 제외하고, 능동문-2항과 능동문-3항 모두 비규범 어순의 표준편차가 규범 어순에 비해 컸는데, 연구 대상 아 동의 연령이 피동문 발달과 마찬가지로 비규범 어순의 문장을 이
해하는 능력도 계속 발달하는 시기임을 확인할 수 있다.

통사 구조와 어순 규범성이 문장 이해에 미치는 효과를 검토하 기 위하여 이원분산분석을 실시한 결과, 통사 구조가 일치하면서 문장의 길이만 다른 능동문-2항과 능동문-3항 간에는 유의한 차 이가 없었으나, 능동문-2항과 피동문, 능동문-3항과 피동문 간 차 이가 유의하였다. 즉, 문장의 길이에서 나타나지 않은 효과가 통사 구조에서 나타났는데, 이는 언어발달기의 아동들의 문장 이해력에 문장의 길이보다는 통사 구조가 더욱 영향을 미치고 있음을 시사 한다. 한편, 능동문-2항의 비규범 어순 수행력( $\mathrm{M}=56.48 \%, \mathrm{SD}=$ $30.86)$ 이 능동문-3항( $\mathrm{M}=67.59, \mathrm{SD}=21.75)$ 및 피동문( $\mathrm{M}=57.41 \%$, $\mathrm{SD}=23.02)$ 의 비규범 어순 수행력보다도 낮았던 점이 흥미롭다. 비 규범 어순에서 수행력이 가장 높았던 능동문-3항은 문장의 길이가 4 어절로 가장 길었는데, 문장의 길이가 길어지는 대신 조사 단서가 추가됨으로써 오히려 문장 이해에 유리한 단서를 제공했을 가능성 을 생각해볼 수 있다. 능동문만 비교해 보더라도 3 어절 문장인 능 동문-2항은 4어절 문장으로 구성된 능동문-3항에 비해 길이가 짧 음에도 불구하고 비규범 어순에서의 수행력이 능동문-3항에 비해 낮았다. 본 연구에서 사용된 능동문-2항의 문항들은 주격조사 '가' 와 목적격조사 '를'로만 구성되었으며, 능동문-3항의 문항들은 주 격조사 '가'와 목적격조사 ‘를', 그리고 부사격조사 '에’ 및 ‘한테’로 구성되어 있다. 즉, 문장에 등장하는 두 행위자에 적용되는 조사가 능동문-2항은 '가'와 ‘를'이며, 능동문-3항은 '가'와 ‘를', 또는 '가'와 '한테'로서, 주체인 행위자와 객체인 행위자를 구별하는 단서가 능 동문-3항이 더 두드러진다. 문장을 이해할 때 어순 전략을 따른다 면 규범 어순보다 불리할 수밖에 없는 비규범 어순에서는, 이러한 청각적 단서가 더욱 유효하게 작용하여 능동문-3항의 비규범 어순 수행력이 능동문-2항에 비해 높았던 것으로 판단된다. 또한 문장 의 길이가 짧은 능동문-2항 비규범 어순에서 조사 '가'와 ‘를'이 문 장 이해에 단서를 제공하지 못하는 점은, 능동문-2항의 비규범 어 순 수행력이 우연수준과 통계적으로 유의한 차이가 없는 것에서도 확인할 수 있다. 한편 비규범 어순에서와 달리 규범 어순에서는 문 장 길이 효과가 더욱 유의하여 4 어절의 능동문-3항에 비해 3 어절의 능동문-2항 수행력이 높게 나타난 것으로 보인다. 정리하자면, 본 연구의 대상 아동들은 행위자를 색깔로 상징화하여 명사의 생물 성이 문장 이해에 미치는 영향을 중립화한 경우 어순전략을 기본 전략으로 사용하는 것으로 나타났으며, 문장성분들을 한국어의 기본적 어순에 맞게 순차적으로 처리하는 규범 어순에서는 문장 의 길이가 짧을수록 수행력이 높았다. 반면 비규범 어순에서는 문 장의 길이가 길수록 수행력이 높았는데, 이는 어순에 의거한 순차 적인 정보처리 경로가 방해받은 상태에서 청각적으로 두드러지는 
조사가 단서를 제공했을 것으로 해석할 수 있다.

문장이해능력을 예측해주는 인지적 요인을 알아보기 위하여 문 장이해 검사의 총점, 그리고 세 가지 통사 구조(능동문-2항, 능동 문-3항, 피동문) 및 어순 규범성(규범 어순, 비규범 어순) 각 범주를 종속변수로 하고 작업기억 과제들을 독립변수로 하여 단계적 회귀 분석을 실시하였다. 그 결과, 문장이해검사의 전체 항목 수행력과 피동문 수행력을 제외한 나머지 하위 검사들에 대해서는 유의한 작업기억 과제가 추출되지 않았으며, 이 두 종속변수를 공통적으 로 예측해주는 작업기억 과제는 '구어 작업기억' 과제인 것으로 나 타났다. 문장이해검사 전체 항목 및 수행력이 가장 낮았던 하위 검 사인 피동문에 대한 수행력만을 구어 작업기억 과제가 예측해주었 다는 점은 3 어절 또는 4 어절로 구성된 문장을 저장하면서 동시에 어순과 조사 등의 문법적 요소를 처리해야 하는 과정에 구어 작업 기억이 중요한 인지적 요인으로 작용함을 시사한다. 본 연구에서 사용한 다섯 가지 작업기억 과제들에 대한 요인분석 결과 구어 작 업기억 과제는 비단어 따라말하기, 숫자 거꾸로 따라말하기, 경쟁 언어 처리 과제 세 가지로 구성되었는데, 이 과제들은 모두 청각적 으로 입력된 언어적 정보를 일시적으로 저장하고 처리하는 과제들 이다. 다른 두 요인으로 분류된 과제 중 매트릭스 과제는 비구어적 정보를 처리하는 과제라는 점에서 차이가 있으며, 문장 따라말하 기 과제는 한국어의 기본적인 어순에 맞고 실제 단어로 이루어져있 는 문장을 회상 산출하는 과제라는 점에서 구어 작업기억 과제와 처리 부담에 차이가 있다. 문장 따라말하기 과제는 과제 수행 시 의 미적 단서를 제공할 수 있는 반면, 구어 작업기억 과제는 생소한 음 소를 저장하고 처리하거나, 입력된 숫자 정보를 거꾸로 회상하여 산출하고, 정보 저장과 처리를 동시에 수행해야 하는 과제들로 구 성되어 있어 과제 수행에 필요한 부하가 문장 따라말하기보다 높을 것임을 유추할 수 있다. 즉, 청각적으로 입력된 구어 정보를 저장하 면서 동시에 처리하는 작업기억 과제들만이 문장이해검사에서 통 사적 복잡성이 높은 과제의 수행력을 유의하게 예측해주는 것으로 나타났는데, 이러한 결과는 정보의 저장과 처리를 동시에 고려한 Just와 Carpenter (1992)의 작업기억용량 이론을 지지한다. 문장이 해검사 전체 및 특히 하위 검사들 중 인지적 부담이 높아지는 피동 문 검사에서 구어 작업기억이 유의하게 작동하였던 것으로 보이며, 이러한 해석은 피동문의 수행력이 다른 두 통사 구조의 수행력에 비해 낮았던 점이 지지해준다고 할 것이다. 다시 말해, 피동문의 수 행력이 두 가지 유형의 능동문에 비해 유의하게 낮았던 것에서 대 상 아동의 문장이해검사에서의 처리 부담의 차이를 확인할 수 있 으며, 능동문에서는 아동의 작업기억을 유의하게 작동시킬만한 처 리 부담이 피동문에 비해 상대적으로 낮았던 것으로 보인다.
본 연구는 조사 단서와 어순 단서만을 사용할 수 있도록 문장이 해검사를 구성하고, 통사 구조와 어순 규범성이 5-6세 일반 아동의 문장이해능력에 상호적으로 영향을 미치며 3-4어절로 구성된 문 장을 처리하는 데 있어서 작업기억이 통사 구조에 따라 다르게 작 용함을 확인하였다. 다만 연구 대상자의 수가 18 명으로 다소 적었 고 성비가 불균형하였으며, 문장이해검사의 조건별 문항 수 또한 6 개씩으로 많지 않았다는 점을 제한점으로 들 수 있을 것이다. 나아 가 피동문 이해 및 표현이 아직 발달 단계인 연구 대상 아동의 연령 을 고려할 때, 보다 높은 연령층을 대상으로 한 연구를 통해 본 연 구의 결과를 보완할 필요가 있을 것으로 보이며, 또한 차후 의사소 통 장애군과의 비교 연구를 통해 문장이해전략 등을 비교 검토함 으로써 언어발달에 있어서의 차이를 검토하고 임상적 의의를 찾을 수 있을 것으로 기대한다.

\section{REFERENCES}

Ahn, J. S., \& Kim, Y. T. (2000). The effect of syntactic complexity on sentence repetition performance and intelligibility between specific language impairment and normal children. Korean Journal of Speech Sciences, 7, 249262.

Alloway, T. P., Gathercole, S. E., Willis, C., \& Adams, A. (2004). A structural analysis of working memory and related cognitive skills in young children. Journal of Experimental Child Psychology, 87, 85-106.

Barrouillet, P., \& Camos, V. (2001). Developmental increase in working memory span: resource sharing or temporal decay? Journal of Memory and Language, 45, 1-20.

Caplan, D., \& Waters, G. S. (1999). Verbal working memory and sentence comprehension. Behavioral and Brain Sciences, 22, 77-126.

Cho, M. (1982). A study on language acquisition of Korean children: strategy model. Seoul: Seoul National University Press.

Conti-Ramsden, G., Botting, N., \& Faragher, B. (2001). Psycholinguistic markers for specific language impairment (SLI). Journal of Child Psychology and Psychiatry, 42, 741-748.

Conway, A. R. A., Bunting, M. F., Engle, R. W., Kane, M. J., Hambrick, D. Z., \& Wilhelm, O. (2005). Working memory span tasks: a methodological review and user's guide. Psychonomic Bulletin \& Review, 12, 769-786.

DeDe, G., Caplan, D., Kemtes, K., \& Waters, G. (2004). The relationship between age, verbal working memory, and language comprehension. Psychology and Aging, 19, 601-616.

Dollaghan, C., \& Campbell, T. (1998). Nonword repetition and child language 
impairment. Journal of Speech, Language \& Hearing Research, 41, 11361146.

Evans, J. L. (2002). Variability in comprehension strategy use in children with SLI: a dynamical systems account. International Journal of language \& Communication Disorders, 37, 95-116.

Gathercole, S. E. (1995). Is nonword repetition a test of phonological memory or long-term knowledge? It all depends on the nonwords. Memory \& Cognition, 23, 83-94.

Gathercole, S. E., Pickering, S. J., Ambridge, B., \& Wearing, H. (2004). The structure of working memory from 4 to 15 years of age. Developmental Psychology, 40, 177-190.

Ha, E. J. (1999). The development of comprehension and production of causative and passive sentence of 4-9 year old normal children (Master's thesis). Ewha Womans University, Seoul, Korea.

Hwang, M. (2003). Sentence comprehension of Korean children with specific language impairments. Korean Journal of Communication \& Disorders, 8, $1-21$.

Hwang, M. (2012). Sentence repetition as a clinical marker of specific language impairment in Korean-speaking preschool children. Korean Journal of Communication \& Disorders, 17, 1-14.

Hwang, M. (2015). Nonword repetition of typically developing children. Communication Sciences \& Disorders, 20, 374-385.

Hwang, M., \& Ahn, H. (2002). The development of sentence interpretation in Korea: the influence of three cues. The Korean Journal of the Human Development, 9, 39-54.

Just, M. A., \& Carpenter, P. A. (1992). A capacity theory of comprehension: Individual differences in working memory. Psychological Review, 99, 122149.

Kim, D. (2002). Basic word order of Korean sentences: establishment of classification criteria. Hanshin Journal of Humanities, 3, 5-27.

Kim, W. K. (2007). Korean passive is a semantic category. Korean Linguistics, $35,219-241$.

Kim, Y. (2014). Semantics and classification of the Korean generic passive sentence. Journal of the Linguistic Society of Korea, 68, 197-217.

Kim, Y. T. (2011). Assessment and treatment of language disorders in children. Seoul: Hakjisa.

Kim, Y. T., Sung, T. J., \& Lee, Y. K. (2011). Preschool Receptive Expressive Language Scale (PRES). Seoul: Seoul Community Rehabilitation Center.

Kim, Y., Lee, C., Kang, B., \& Nam, S. (2000). The semantics structure and argument realization of Korean passive verbs. Korean Journal of Cognitive
Science, $11,25-32$.

King, J., \& Just, M. A. (1991). Individual differences in syntactic processing: The role of working memory. Journal of Memory and Language, 30, 580602.

Kwak, K. C., Oh, S. W., \& Kim C. T. (2011). Korean-Wechsler Intelligence Scale for Children-IV (K-WISC-IV). Seoul: Hakjisa.

Kwon, D., \& Jeong, B. (2000). The development of particles in the normal children aged from 2 to 5 years. Journal of Speech \& Hearing Disorders, 9(1), 139-163.

Lee, J. T. (2004). The definition of passive and passive predicate. Korean Linguistics, 22, 335-354.

Loeb, D. F., Pye, C., Richardson, L. Z., \& Redmond, S. (1998). Causative alternations of children with specific language impairment. Journal of Speech, Language, \& Hearing Research, 41, 1103-1114.

Magimairaj, B. M., \& Montgomery, J. W. (2012) Children's verbal working memory: role of processing complexity in predicting spoken sentence comprehension. Journal of Speech, Language, and Hearing Research, 55, $669-682$.

Mainela-Arnold, E., \& Evans, J. L. (2005). Beyond capacity limitations: determinants of word recall performance on verbal working memory span tasks in children with SLI. Journal of Speech, Language \& Hearing Research, 48, 897-909.

Maratsos, M., Becker, J. A., \& Chalkley, M. A. (1985). Semantic restrictions on children's passives. Cognition, 19, 167-191.

Marton, K., \& Schwartz, R. G. (2003). Working memory capacity and language processes in children with specific language impairment. Journal of Speech, Language, and Hearing Research, 46, 1138-1153.

Montgomery, J. W. (1995). Sentence comprehension in children with specific language impairment: the role of phonological working memory. Journal of Speech and Hearing Research, 38, 187-199.

Montgomery, J. W. (2000). Verbal working memory and sentence comprehension in children with specific language impairment. Journal of Speech, Language \& Hearing Research, 43, 293-308.

Montgomery, J. W., \& Evans, J. L. (2009). Complex sentence comprehension and working memory in children with specific language impairment. Journal of Speech, Language \& Hearing Research, 52, 269-288.

Montgomery, J. W., Magimairaj, B. M., \& O’Malley, M. H. (2008). Role of working memory in typically developing children's complex sentence comprehension. Journal of Psycholinguistic Research, 37, 331-354.

Moon, S. B., \& Byun, C. J. (2003). Korean Kaufman assessment battery for 
children (K-ABC). Seoul: Hakjisa.

Oh, D. Y., \& Yim, D. (2013). Non-word repetition and sentence repetition performance in 2-3 years old late talkers and normal children. Communication Sciences \& Disorders, 18, 277-287.

Pae, S. (1995). Language development of Korean children: primary data of language development diagnosis. In Speech-Language Therapist Training. Seoul: The Korean Academy of Speech-Language Pathology and Audiology.

Shin, S. I. (2007). A study on the tendency and the factors of word order variations in Korean. Journal of Korea Linguistics, 50, 213-239.

Slobin, D. I. (1966). Grammatical transformations and sentence comprehension in childhood and adulthood. Journal of Verbal Learning and Verbal Behavior, 5, 219-227.

Strohner, H., \& Nelson, K. E. (1974). The young child's development of sentence comprehension: influence of event probability, nonverbal context, syntactic form, and strategies. Child Development, 45, 567-576.

Sung, J. E. (2015). Effects of syntactic structure on sentence comprehension ability as a function of the canonicity of word-orders and its relation to working memory capacity in Korean-speaking elderly adults. Communication Sciences \& Disorders, 20, 24-33.

Sung, K. (1992). A study of Korean word order. Hangul, 218, 77-114.
Waters, G. S., \& Caplan, D. (2003). The reliability and stability of verbal working memory measures. Behavior Research Methods, Instruments, \& Computers, 35, 550-564.

Waters, G. S., \& Caplan, D. (2004). Verbal working memory and on-line syntactic processing: evidence from self-paced listening. Quarterly Journal of Experimental Psychology, 57, 129-163.

Weismer, S. E., Evans, J., \& Hesketh, L. J. (1999). An examination of verbal working memory capacity in children with specific language impairment. Journal of Speech, Language, and Hearing Research, 42, 1249-1260.

Wu, C., Vissiennon, K., Friederici, A. D., \& Brauer, J. (2016). Preschoolers' brains rely on semantic cues prior to the mastery of syntax during sentence comprehension. NeuroImage, 126, 256-266.

Yi, S. H. (2000). The acquisition of Korean grammatical morphemes in early childhood. Korean Journal of Child Study, 21, 51-68.

Yim, D., Kim, S., \& Yang, Y. (2015). Factor analysis of working memory tasks based on information processing characteristics: predictive factors of receptive vocabulary and quick incidental learning in children with typically developing and receptive vocabulary delay. Communication Sciences \& Disorders, 20, 304-318. 
Shin-Young Kim, et al. • Relationship between Sentence Comprehension Ability and Working Memory

Appendix 1. 문장이해검사의 문장유형별 목표문장의 예시

\begin{tabular}{|c|c|c|}
\hline \multicolumn{2}{|c|}{ 문장 유형 } & \multirow{2}{*}{ 목표 문장 } \\
\hline 통사 구조 & 어순 규범성 & \\
\hline 능동문-2항 & $\begin{array}{l}\text { 규범 어순 } \\
\text { 비규범 어순 }\end{array}$ & $\begin{array}{l}\text { 파랑이가 검정이를 잡아요. } \\
\text { 파랑이를 노랑이가 밀어요. }\end{array}$ \\
\hline 능동문-3항 & $\begin{array}{l}\text { 규범 어순 } \\
\text { 비규범 어순 }\end{array}$ & $\begin{array}{l}\text { 검정이가 노랑이를 나무에 묶어요. } \\
\text { 파랑이한테 노랑이가 사과를 던져요 }\end{array}$ \\
\hline 피동문 & $\begin{array}{l}\text { 규범 어순 } \\
\text { 비규범 어순 }\end{array}$ & $\begin{array}{l}\text { 검정이가 파랑이한테 잡혀요. } \\
\text { 노랑이한테 파랑이가 밀려요. }\end{array}$ \\
\hline
\end{tabular}

Appendix 2. 문장이해검사의 그림 예시

목표 문장: 검정이가 노랑이한테 쫓겨요.

\section{문항 2}
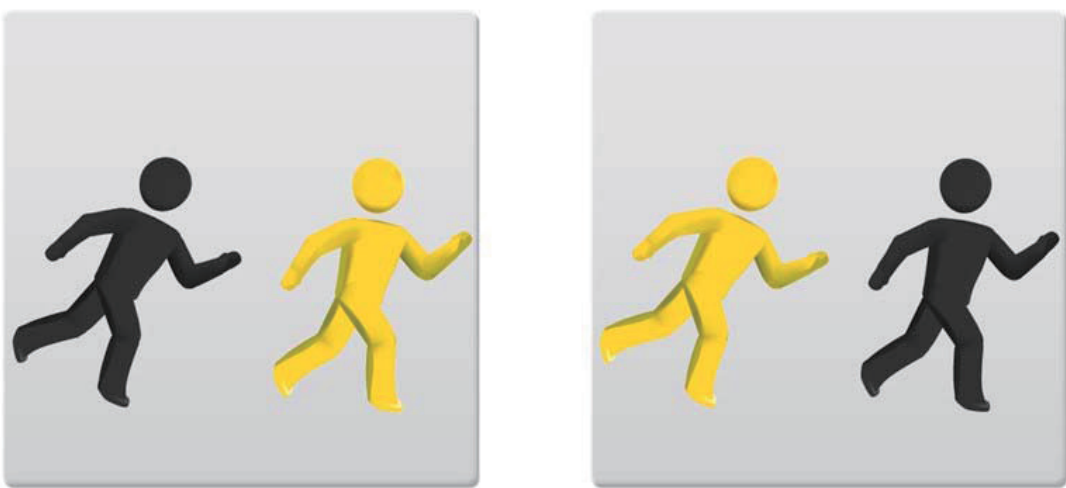


\section{국문초록}

\section{통사 구조와 어순 규범성이 5-6세 아동의 문장이해능력에 미치는 영향 및 작업기억과의 관계 김신영 · 성지은 · 임동선 \\ 이화여자대학교 대학원 언어병리학과}

배경 및 목적: 본 연구는 학령전기 아동의 문장이해 과정에서 의미적 단서의 영향을 최소화했을 때 형태론 및 통사론적 단서가 미치는 영향을 살펴보고, 문장이해능력을 예측하는 작업기억 과제의 유형을 검토하고자 하였다. 방법: 만 5-6세 일반 아동 18 명을 대상으로, 3 개의 통사 구조(능동문-2항, 능동문-3항, 피동문)와 2 개의 어순 규범성(규범 어순, 비규범 어순) 조건으로 구성된 문장이해검사를 실시 하여 각 하위유형에 따른 문장이해능력의 차이를 비교 검토하였다. 또한 5 가지 작업기억 과제(비단어 따라말하기, 숫자 거꾸로 따라말 하기, 경쟁 언어 처리 과제, 문장 따라말하기, 매트릭스)를 대상으로 탐색적 요인분석을 실시하여 문장이해능력에 대한 작업기억의 설명 력을 검토하였다. 결과: 문장이해검사 수행력에 대한 반복측정 이원분산분석 결과, 통사구조 및 어순 규범성의 주효과가 모두 유의하 였다. 사후검정 결과 피동문의 정반응률이 능동문에 비해 유의하게 낮았으며, 비규범 어순의 정반응률이 규범 어순의 정반응률보다 유의하게 낮았다. 작업기억 과제에 대한 탐색적 요인분석 결과, 5 개의 작업기억 과제가 3 개의 요인(구어 작업기억, 매트릭스, 문장 따라 말하기)으로 분류되었으며, 문장이해능력을 유의하게 예측해주는 과제는 '구어 작업기억 과제'인 것으로 나타났다. 논의 및 결론: 통사 구조 및 어순 규범성이 5-6세 일반 아동의 문장이해능력에 영향을 미침을 확인하였으며, 특히 통사적 복잡성이 높은 문장에 대한 수행 력을 작업기억 용량이 유의하게 예측해줌을 확인하였다.

핵심어: 통사 구조, 어순 규범성, 문장이해능력, 작업기억

이 논문은 대한민국 교육부와 한국연구재단의 지원을 받아수행된 연구임(NRF-2017R1A2B4006604).

\section{참고문헌}

곽금주, 오상우, 김청택(2011). 한국판 웩슬러 아동용 지능검사(K-WISC-IV). 서울: 학지사.

권도하, 정분선(2000). 2-5세 아동의 조사 발달 연구. 언어치료연구, 9, 139-163.

김동식(2002). 국어 문장의 기본 어순에 관하여: 어순 판별 기준의 설정을 위하여. 한신인문학연구, 3, 5-27.

김영태(2011). 아동언어장애의 진단 및 치료. 서울: 학지사.

김영태, 성태제, 이윤경(2011). 취학전 아동의 수용언어 및 표현언어 발달척도(PRES). 서울: 장애인 종합복지관.

김원경(2007). 피동은 문법 범주인가? 한국어학, 35, 219-241.

김윤신(2014). 국어 총칭 피동문의 유형과 의미. 언어학, 68, 197-217.

김윤신, 이정민, 강범모, 남승호(2000). 한국어 피동동사의 의미구조와 논항실현. 인지과학, 11, 25-32.

문수백, 변창진(2003). K-ABC 교육·심리측정도구(Korean-Kaufman assessment battery for children). 서울: 학지사.

배소영(1995). 우리 나라 아동의 언어발달: 언어발달진단의 일차적 자료. 언어치료 전문요원교육(한국언어병리학회 편). 서울: 한국언어병리학회.

성기철(1992). 국어 어순 연구. 한글, 218, 77-114.

성지은(2015). 한국어 어순 규범성과 문장유형이 노년층 문장이해능력에 미치는 영향 및 작업기억 용량과의 관계. 언어청각장애연구, 20, 24-33.

신서인(2007). 한국어의 어순 변이 경향과 그 요인에 대한 연구. 국어학, 50, 213-239.

안지숙, 김영태(2000). 단순언어장애 아동과 정상 아동의 구문적 난이도에 따른 문장따라말하기: 수행력 및 명료도 비교. 음성과학, 7,249-262.

오다연, 임동선(2013). 2-3세 말 늦은 아동과 정상 아동의 비단어따라말하기와 문장 따라말하기 수행 능력. 언어청각장애연구, 18, 277-287.

이순형(2000). 한국아동이초기에 획득한 문법적 형태소의 종류 및 획득 시기. 아동학회지, 21, 51-68.

이정택(2004). 피동의 개념과 피동 서술어. 한국어학, 22, 335-354. 
임동선, 김신영, 양윤희(2015). 정보처리 특성에 따른 작업기억 과제의 탐색적 요인분석: 일반아동 및 수용어휘지체 아동의 수용어휘력 및 빠른우연 학습 예측요인. 언어청각장애연구, 20,304-318.

조명한(1982). 한국아동의 언어획득 연구: 책략 모형. 서울: 서울대학교 출판부.

하은진(1999). 사동문과 피동문의 이해 및 표현 발달에 관한 연구. 이화여자대학교 대학원 석사학위논문.

황민아(2003). 단순언어장애아동의 문장 이해: 단서이용 양상을 중심으로. 언어청각장애연구, 8, 1-21.

황민아(2012). 문장따라말하기 검사의 학령 전 단순언어장애 진단 정확도. 언어청각장애연구, 17, 1-14.

황민아(2015). 일반아동의 비단어 따라말하기. 언어청각장애연구, 20, 374-385.

황민아, 안혜진(2002). 아동과 성인의 문장이해에서 의미, 조사, 어순단서의 활용 양상. 인간발달연구, 9, 39-54. 